\title{
Geographic Information Systems Application to Drought Distribution Identification with Standardized Precipitation Index (SPI) Method in Trenggalek Regency
}

Penerapan Sistem Informasi Geografis Untuk Mengidentifikasi Sebaran Kekeringan Dengan Metode Standardized Precipitation Index (SPI) Di Kabupaten Trenggalek

\author{
Received: \\ 4 February 2021 \\ Revised: \\ 18 July 2021 \\ Published: \\ 8 August 2021
}

\author{
${ }^{1 *}$ Aditya Utama, ${ }^{2}$ Mohammad Pramono Hadi, ${ }^{3}$ Emilya Nurjani \\ ${ }^{1}$ Magister Ilmu Lingkungan minat Geo-Informasi untuk Manajemen \\ Bencana, Universitas Gadjah Mada \\ ${ }^{2,3}$ Fakultas Geografi, Universitas Gadjah Mada \\ ${ }_{1,2,3}$ Yogyakarta, Indonesia \\ E-mail: ${ }^{1}$ adityautama@mail.ugm.ac.id, ${ }^{2}$ mphadi@yahoo.com, \\ 3emilya.nurjani@ugm.ac.id
}

*Corresponding Author

\begin{abstract}
The widespread drought area in Trenggalek Regency in 2019 needs to be analyzed to reduce negative impacts and as a monitoring tool to anticipate future drought events. The Standardized Precipitation Index (SPI) is a drought analysis method by calculating the rainwater deficit at various time scales used to identify the distribution of drought in Trenggalek Regency. This study using rain data on 13 rain stations for the period 1990-2019 and agricultural production data for 2019. The calculation results show that the highest SPI value occurred in March at the highly wet level with a value of 2.11. The lowest SPI value occurred in May at the extremely dry level with a value of -2.31. The results are then mapped using ArcGIS with the Inverse Distance Weighted (IDW) method to identify the spatial distribution of drought.
\end{abstract}

Keyword-Drought, Standardized Precipitation Index (SPI), Agricultural Production, Trenggalek Regency.

Abstrak - Wilayah kekeringan yang semakin meluas di Kabupaten Trenggalek pada tahun 2019 perlu dianalisis untuk menekan dampak negatif serta sebagai alat pantau guna mengantisipasi kejadian kekeringan di masa mendatang. Standardized Precipitation Index (SPI) adalah salah satu metode analisis kekeringan dengan menghitung defisit air hujan pada berbagai skala waktu yang digunakan untuk mengidentifikasi sebaran kekeringan di Kabupaten Trenggalek. Data yang digunakan dalam penelitian adalah data hujan pada 13 stasiun hujan periode 1990-2019 dan data produksi pertanian tahun 2019 di Kabupaten Trenggalek. Hasil perhitungan didapat nilai SPI tertinggi terjadi pada bulan Maret pada tingkat ekstrim basah dengan nilai 2,11. Untuk nilai SPI terendah terjadi pada bulan Mei pada tingkat ekstrim kering dengan nilai -2,31. Hasil tersebut selanjutnya dipetakan dengan ArcGIS menggunakan metode Inverse Distance Weighted (IDW) untuk identifikasi sebaran kekeringan secara spasial

Kata Kunci- kekeringan, standardized precipitation index (spi), produksi pertanian, kabupaten trenggalek 


\section{INTRODUCTION}

Drought is one of the extreme events where the amount of rain that falls is lower than the amount of evapotranspiration that occurs, resulting in an air deficit. [1]. Drought occurs slowly and is not known with certainty initially and ends with a pattern of events that can change from time to time [2]. Damage due to drought is very costly. The losses to the economic, social, and environmental sectors are continuously increasing to affect significantly human life compared to other disasters [3]. The impact of drought is often not as tangible as other disasters such as floods, landslides, earthquakes, and tsunamis which often cause structural damage to buildings.

Drought events usually begin with a meteorological drought where there is no rain in an area for a certain period. It can then trigger agricultural drought. It is characterized by reduced soil moisture, which causes the inability to meet the needs of plants for water in certain areas and periods. If the drought period has not ended, it can then trigger a hydrological drought. The decrease in groundwater level, wells, rivers, reservoirs, and lakes indicates a lack of groundwater, and surface water supply is one of the characteristics of this drought.

Trenggalek Regency is one of the regencies located in the southern part of East Java Province. It has a mountainous coastal area with an altitude of 0 to 690 meters above sea level and an area of $1,261.40 \mathrm{~km} 2$, where $2 / 3$ of the area is mountainous [4]. It makes Trenggalek Regency prone to multi-disaster threats, such as tsunamis on the south coast, landslides in mountainous areas where most of the topography is steep, floods, and droughts that occur almost every year. Based on data from the Trenggalek Regency BPBD from 2017 to 2019, the number of villages affected by drought always increases. From 38 villages in 2017, it increased to 43 villages in 2018, and in 2019, it became 66 villages. During this period, the majority of villages affected by drought were permanent [5]. In line with this, data from the Agriculture and Food Service of Trenggalek Regency shows a decrease in total rice and secondary food production from 508,204 tons in 2018, decreasing by 22,128 tons in 2019486,076 tons [6]. In the agricultural sector, drought due to the El Nino phenomenon can cause a decrease in rice and secondary crops production in the range of $1.67 \%$ to $5.67 \%$ [7]. It proves that plants need a sufficient amount and distribution of rain during the planting period [8].

One of the methods used for drought index analysis is the Standardized Precipitation Index (SPI) [9]. SPI is an easy-to-use method because it only uses observational rainfall data to measure the meteorological drought level. The World Meteorological Organization (WMO) has recommended the SPI as a universal meteorological drought index for monitoring and early warning systems against drought hazards [2]. Therefore, many countries on various continents 
INTENSIF, Vol.5 No.2 August 2021

ISSN: 2580-409X (Print) / 2549-6824 (Online)

DOI: https://doi.org/10.29407/intensif.v5i2.15645

use SPI for meteorological drought monitoring [10], such as Europe [11]-[15], Africa [16], [17], America [18], Australia [19] and Asia [20]-[24].

The drought index is then utilized in a geographical map to determine the distribution of drought using a Geographic Information System (GIS). GIS is a set of technology, software, human resources, and data that may be used to enter, store, enhance, update, manage, modify, integrate, analyze, and display data in a geographically oriented information system [25]. The GIS is used in the drought map processing in ArcGIS 10.6.1.

This study aims to identify the distribution of drought in the Trenggalek Regency using the SPI method and the effect of drought on rice and secondary crops production in the Trenggalek Regency. There is no much research related to the drought effect on rice and secondary crops. One of the reasons behind this is that the availability of agricultural land is only approximately $10 \%$ of the total area of the Trenggalek Regency. Farmers must be able to cultivate crops appropriately and effectively. In addition, this is also an effort to overcome drought events, especially in Java, which is projected until 2030 to experience a more extended dry season [26].

\section{RESEARCH METHOD}

This study uses the SPI method that utilizes rainfall data as the primary input in the calculation process. Rainfall data comes from 13 rain stations spread across Trenggalek Regency with details of 12 rain stations under the auspices of the Trenggalek Regency Public Works and Spatial Planning Office and one rain station belonging to Perum Jasa Tirta I. The rainfall data used has a recording period of 30 years, between 1990 and 2019. The use of rainfall data for a minimum of 30 years is ideal for calculating the SPI method's drought index [9].

The first step of this research is to test the completeness and consistency of rain data. The existence of data gaps caused by damage to the rain gauge will be complemented by utilizing image data from CHIRPS. CHIRPS data has a strong relationship and a good level of accuracy with observation data at rain stations in East Java Province, Trenggalek Regency [27]. An example of rain data after the completeness and consistency test is shown in Table 1, the rain data for 2019. 
INTENSIF, Vol.5 No.2 August 2021

ISSN: 2580-409X (Print) / 2549-6824 (Online)

DOI: https://doi.org/10.29407/intensif.v5i2.15645

Table 1. RAIN DATA For 2019 In TRENGGALEK REgENCY

\begin{tabular}{|c|c|c|c|c|c|c|c|c|c|c|c|c|}
\hline \multirow{2}{*}{$\begin{array}{c}\text { Rain } \\
\text { Station }\end{array}$} & \multicolumn{12}{|c|}{ Month (mm) } \\
\hline & Jan & $\mathrm{Feb}$ & Mar & Apr & May & Jun & Jul & Aug & Sep & Oct & Nov & Dec \\
\hline Bendungan & 324 & 472 & 654 & 221 & 52 & 39 & 24 & 0 & 0 & 0 & 128 & 408 \\
\hline Bagong & 378 & 305 & 453 & 242 & 0 & 25 & 10 & 0 & 0 & 0 & 38 & 324 \\
\hline Tugu & 312 & 220 & 399 & 307 & 0 & 33 & 15 & 0 & 0 & 0 & 27 & 227 \\
\hline Prambon & 229 & 209 & 481 & 218 & 0 & 9 & 3 & 0 & 0 & 0 & 31 & 308 \\
\hline Jabung & 256 & 243 & 535 & 182 & 4 & 18 & 11 & 7 & 0 & 0 & 24 & 160 \\
\hline Widoro & 280 & 167 & 313 & 114 & 1 & 16 & 4 & 1 & 0 & 0 & 22 & 110 \\
\hline Kampak & 322 & 171 & 287 & 195 & 30 & 9 & 11 & 0 & 0 & 2 & 81 & 131 \\
\hline Pule & 298 & 246 & 416 & 189 & 5 & 0 & 4 & 0 & 0 & 0 & 6 & 177 \\
\hline Dongko & 403 & 315 & 604 & 265 & 29 & 28 & 17 & 0 & 0 & 0 & 163 & 241 \\
\hline Munjungan & 322 & 171 & 513 & 297 & 36 & 8 & 0 & 0 & 0 & 0 & 224 & 78 \\
\hline Panggul & 483 & 94 & 424 & 95 & 29 & 6 & 17 & 0 & 0 & 0 & 144 & 127 \\
\hline Bendo & 288 & 254 & 195 & 82 & 2 & 16 & 7 & 5 & 0 & 4 & 19 & 117 \\
\hline Watulimo & 338 & 90 & 343 & 301 & 154 & 51 & 45 & 16 & 1 & 82 & 125 & 17 \\
\hline
\end{tabular}

After the rain data is tested, the second step is to calculate the SPI value based on the number of gamma distributions, which are defined as a function of frequency or probability of occurrence as follows:

$$
G(x)=\int_{0}^{x} g(x) d x=\frac{1}{\beta^{x} \Gamma(\alpha)} \int_{0}^{x} t^{\alpha-1} e^{\frac{-x}{\beta}} d x
$$

The values of $\alpha$ and $\beta$ are estimated for each rain station using the following formula::

$$
\begin{aligned}
& \alpha=\frac{\bar{x}^{2}}{S d^{2}} \\
& \beta=\frac{\bar{x}}{\sigma}
\end{aligned}
$$

The gamma function is undefined for $\mathrm{x}=0$, so the value of $\mathrm{G}(\mathrm{x})$ becomes :

$$
H(x)=q+(1-q) \cdot G(x)
$$

Where $\mathrm{q}=$ number of rain events $=0(\mathrm{~m}):$ amount of data $(\mathrm{n})$.

The SPI value is a transformation from the gamma distribution $(\mathrm{G}(\mathrm{x}))$ to a normal standard with an average of 0 and a difference of 1 . The calculation of the SPI value for $0<\mathrm{H}(\mathrm{x}) \leq 0,5$ is as follow : 
INTENSIF, Vol.5 No.2 August 2021

ISSN: 2580-409X (Print) / 2549-6824 (Online)

DOI: https://doi.org/10.29407/intensif.v5i2.15645

$$
S P I=-\left(t-\frac{c_{0}+c_{1} t+c_{2} t^{3}}{1+d_{1}+d_{2} t^{3}+d_{12} t^{3}}\right)
$$

With $\quad t=\sqrt{\ln \left(\frac{1}{(H(x))^{2}}\right.}$

The calculation of the SPI value for $0,5<\mathrm{H}(\mathrm{x}) \leq 1,0$ is as follow :

$$
S P I=+\left(t-\frac{c_{0}+c_{1} t+c_{2} t^{3}}{1+d_{1}+d_{2} t^{2}+d_{12} t^{3}}\right)
$$

With

$$
t=\sqrt{\ln \left(\frac{1}{1,0-(H(x))^{2}}\right.}
$$

with the following coefficient values:

$$
\begin{aligned}
& \mathrm{c}_{0}=2,515517 \\
& \mathrm{c}_{1}=0,802853 \\
& \mathrm{c}_{2}=0,010328
\end{aligned}
$$$$
\mathrm{d}_{1}=1,432788
$$$$
\mathrm{d}_{2}=0,189269
$$$$
\mathrm{d}_{3}=0,001308
$$

The calculation period can be adjusted based on the allocation of the calculation results, such as $1,3,6$, or 12 months. Drought is identified when the SPI value is less than or equal to -1 and occurs continuously. Classification of drought levels based on SPI values is in Table 2.

Table 2. Classification Of THE SPI METHOD'S DRY RATE [28]

\begin{tabular}{cc}
\hline \hline SPI Value & Clarification \\
\hline $\mathrm{SPI} \geq 2,0$ & Extremely Wet \\
\hline $1,5 \leq \mathrm{SPI} \leq 1,99$ & Very wet \\
\hline $1,0 \leq \mathrm{SPI} \leq 1,49$ & Medium Wet \\
\hline $0 \leq \mathrm{SPI} \leq 0,99$ & Slightly Wet \\
\hline$-0,99 \leq \mathrm{SPI} \leq 0$ & Slightly Dry \\
\hline$-1,49 \leq \mathrm{SPI} \leq-1,0$ & Medium Dry \\
\hline$-1,99 \leq \mathrm{SPI} \leq-1,5$ & Very Dry \\
\hline $\mathrm{SPI} \leq-2,0$ & Extremely Dry
\end{tabular}

The third step is to create a drought distribution map based on SPI calculations using ArcGIS 10.6.1 software using the Inverse Distance Weighted (IDW) method. The map that has been made is then analyzed spatially to determine the droughts distribution in Trenggalek Regency in 2019. The fourth step is to conduct a descriptive analysis to determine the effect of drought events on agricultural productivity in the Trenggalek Regency. Data on rice and secondary crops production in 2019 obtained from the Agriculture and Food Service of Trenggalek Regency are shown in Table 3. 
Table 3. Rice AND SECONDARy CROPS PRODUCTION DATA In 2019 In TRENGGALEK REGENCY

\begin{tabular}{cc}
\hline \hline Commodity & Production (tons) \\
\hline Rice & 163.807 \\
\hline Corn & 110.052 \\
\hline Soya bean & 4.800 \\
\hline Peanuts & 3.055 \\
\hline Mung beans & 94 \\
\hline Cassava & 183.107 \\
\hline Sweet potato & 21.161 \\
\hline
\end{tabular}

\section{RESULT AND DISCUSSION}

\section{A. Drought Index}

The calculation of the drought index uses rain data that has been tested for completeness and consistency. The SPI 1 drought index calculation results are shown in Table 4 by following the drought level classification in Table 2. The use of monthly periods in making the drought index aims to determine how the rainwater deficit affects the area affected by drought and the rise and fall of rice and secondary crops production in each month discussed in the following subchapter.

Based on the analysis results, the Dam station is the only rain station that did not detect a drought in 2019. The worst drought event occurred in May, where drought was detected at ten stations with a drought classification of "medium dry" to "extremely dry." The highest drought index in 2019 was also read in May with a value of -2.31, which occurred at Widoro station. Despite reducing the number of stations reporting drought in June, three stations remained in the "medium dry" category.

The drought that hit almost all areas of the Trenggalek Regency occurred again in November. Drought events were detected at seven stations, most of which were the same as the drought in May, with details of two index values at the "very dry" level and five others at the "medium dry" level. In December, although only three rain stations indicated drought, the level of drought that occurred was classified as severe, namely two with the "very dry" classification and one with the "extremely dry" classification with a value of -2.1.

Table 4. Spi Drought IndeX VALue 1 The Year 2019 In TRENGGaLeK Regency

\begin{tabular}{lcccccccccccc}
\hline \multirow{2}{*}{$\begin{array}{c}\text { Rain } \\
\text { Station }\end{array}$} & Jan & Feb & Mar & Apr & May & Jun & Jul & Aug & Sep & Oct & Nov & Dec \\
\hline Bendungan & 0,22 & 1,24 & 1,45 & $-0,38$ & $-0,99$ & $-0,16$ & $-0,1$ & 0 & $-0,25$ & $-0,84$ & $-0,75$ & 0,57 \\
\hline Bagong & 0,64 & 0,53 & 1,42 & 0,24 & $-1,5$ & $-0,19$ & $-0,11$ & $-0,08$ & 0 & $-0,97$ & $-1,19$ & 0,58 \\
\hline Tugu & $-0,26$ & $-1,2$ & 0,91 & 0,49 & $-1,11$ & $-0,36$ & 0,16 & 0,25 & 0,52 & $-0,43$ & $-1,44$ & $-0,23$ \\
\hline
\end{tabular}


INTENSIF, Vol.5 No.2 August 2021

ISSN: 2580-409X (Print) / 2549-6824 (Online)

DOI: https://doi.org/10.29407/intensif.v5i2.15645

\begin{tabular}{|c|c|c|c|c|c|c|c|c|c|c|c|c|}
\hline \multirow{2}{*}{$\begin{array}{c}\text { Rain } \\
\text { Station }\end{array}$} & \multicolumn{12}{|c|}{ Month } \\
\hline & Jan & Feb & Mar & Apr & May & Jun & Jul & Aug & Sep & Oct & Nov & Dec \\
\hline Prambon & $-0,28$ & $-0,62$ & 1,78 & 0,37 & $-1,28$ & $-0,45$ & $-0,35$ & 0,08 & $-0,08$ & $-0,62$ & $-1,51$ & 0,87 \\
\hline Jabung & $-0,11$ & 0,08 & 2,11 & 0,41 & $-1,41$ & $-0,43$ & $-0,06$ & 0,13 & 0,08 & $-0,84$ & $-1,22$ & $-0,29$ \\
\hline Widoro & 0,37 & $-0,49$ & 0,92 & $-0,35$ & $-2,31$ & $-0,48$ & $-0,57$ & $-0,53$ & $-0,43$ & $-1,11$ & $-1,41$ & $-0,72$ \\
\hline Kampak & 0,31 & $-0,88$ & 0,36 & $-0,05$ & $-1,32$ & $-1,45$ & $-0,68$ & $-0,73$ & $-1,5$ & -1 & $-0,91$ & $-0,76$ \\
\hline Pule & $-0,2$ & $-0,46$ & 0,81 & $-0,12$ & $-1,44$ & $-1,11$ & $-0,72$ & $-0,17$ & $-0,52$ & $-0,73$ & $-1,82$ & $-0,59$ \\
\hline Dongko & 0,15 & $-0,26$ & 1,53 & $-0,02$ & $-1,46$ & $-0,73$ & $-0,34$ & $-0,25$ & $-0,52$ & $-0,84$ & $-0,32$ & $-0,54$ \\
\hline Munjungan & 0,19 & $-0,88$ & 1,21 & $-0,17$ & $-1,22$ & $-1,16$ & $-0,62$ & 0 & $-0,17$ & $-0,84$ & $-0,54$ & $-1,83$ \\
\hline Panggul & 1,11 & -2 & 1,22 & $-1,09$ & $-0,87$ & $-0,98$ & $-0,16$ & 0 & $-0,52$ & $-0,97$ & $-0,7$ & $-1,58$ \\
\hline Bendo & 0,45 & 0,46 & 0,18 & $-0,47$ & $-1,35$ & $-0,26$ & $-0,17$ & 0,08 & $-0,17$ & $-0,78$ & $-1,26$ & $-0,43$ \\
\hline Watulimo & 0,79 & $-1,36$ & 0,69 & 0,61 & 0,07 & $-0,59$ & $-0,33$ & $-0,47$ & $-0,7$ & $-0,24$ & $-0,67$ & $-2,1$ \\
\hline Info.: & \multicolumn{3}{|c|}{$\begin{array}{l}\text { Extremely wet } \\
\text { Slightly dry }\end{array}$} & \multicolumn{2}{|c|}{$\begin{array}{l}\text { Very wet } \\
\text { Medium dry }\end{array}$} & & \multicolumn{2}{|c|}{$\begin{array}{l}\text { Medium-wet } \\
\text { Very dry }\end{array}$} & \multicolumn{3}{|c|}{$\begin{array}{l}\text { Slightly wet } \\
\text { Extreme/y dry }\end{array}$} & \\
\hline
\end{tabular}

Source: Data Processing 2020

The SPI-1 drought index has characteristics that are very sensitive to rainfall. Figure 1 shows how the SPI-1 value drops when the monthly rainfall is likewise low, according to the analysis results. SPI-1 calculates the value of the drought index by comparing rainfall data for one month with rain data for the same month in another year.

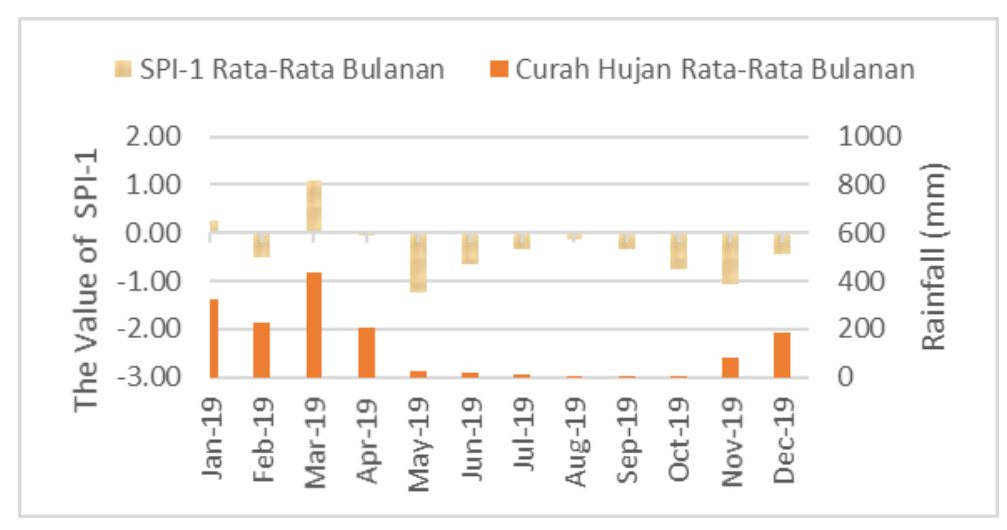

Figure 1. GRAPH OF SPI-1 InDEX VALUE AND RAINFALl In TRENGGALEK District In 2019

B. Drought Distribution

A drought distribution map was made to facilitate the spatial and temporal identification of droughts in the Trenggalek Regency in 2019. The map used ArcGIS 10.6.1 software, with the primary input used in making the map is the calculation result of SPI 1 at each rain station. The SPI values are then interpolated using the IDW method. The resulting drought distribution map is shown in Figure 2. 
INTENSIF, Vol.5 No.2 August 2021

ISSN: 2580-409X (Print) / 2549-6824 (Online)

DOI: https://doi.org/10.29407/intensif.v5i2.15645

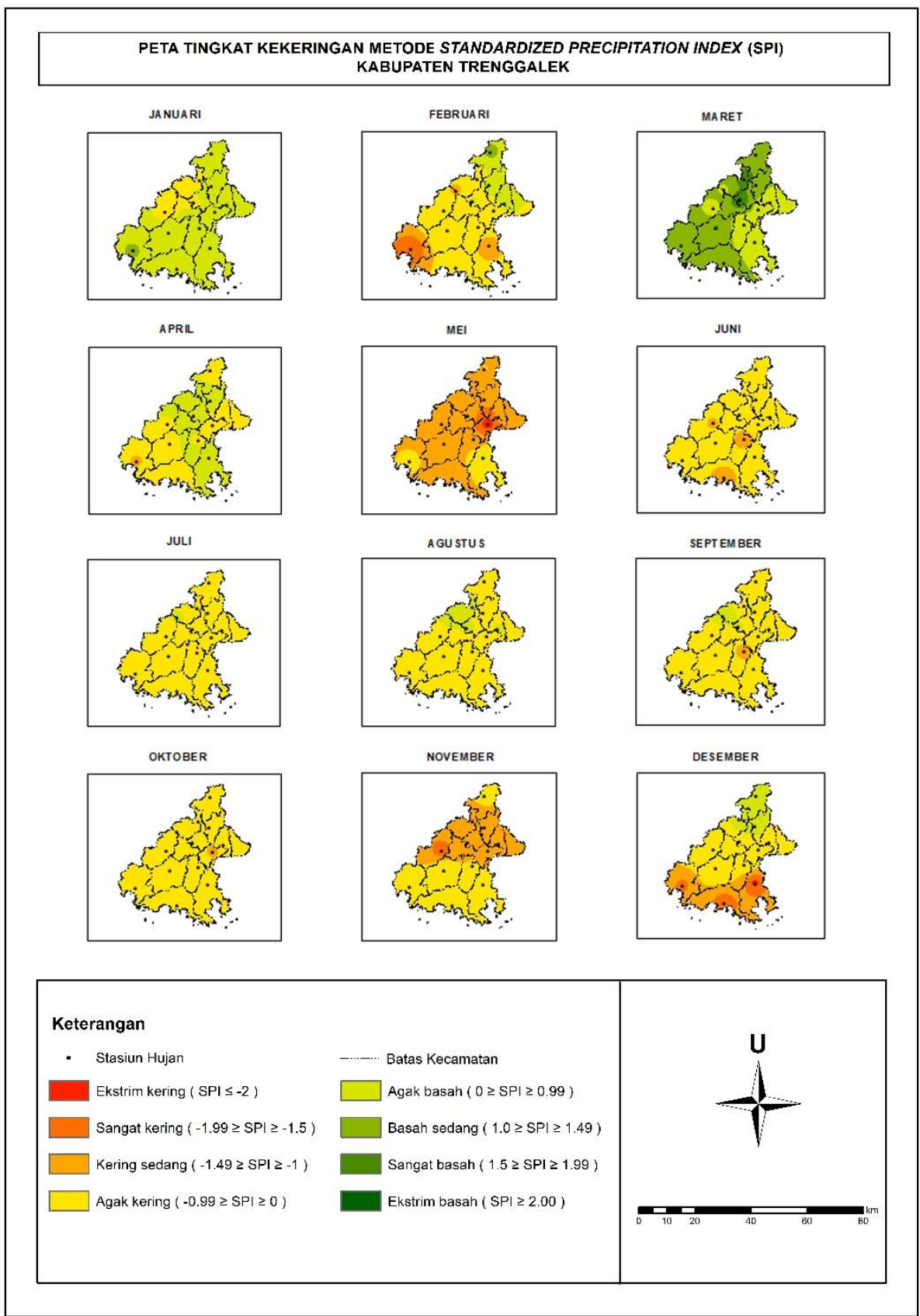

Figure 2. MAP Distribution Of THE Drought YEAR 2019 SPI 1 District TRENGGALEK

The analysis results based on the resulting map show how the influence of the SPI value on the drought conditions that occur in the area around the rain station point. The majority of SPI values less than -1 in May spread the effects of the drought throughout virtually the entire Trenggalek Regency. Table 3 shows that in that month, the area affected by drought at the "medium dry" level reached $78.16 \%\left(976,102 \mathrm{~km}^{2}\right)$. The Widoro rain station that detects drought at the "extremely dry" level makes the drought conditions in that month even worse. There are 
INTENSIF, Vol.5 No.2 August 2021

ISSN: 2580-409X (Print) / 2549-6824 (Online)

DOI: https://doi.org/10.29407/intensif.v5i2.15645

$1.18 \%\left(14,753 \mathrm{~km}^{2}\right)$ of the area affected at the drought level and $5.77 \%\left(72,079 \mathrm{~km}^{2}\right)$ of the area at the "very dry" level, which is a transition area; from "extremely dry" to "medium dry."

Table 5. Percentage Of Drought Area In 2019

\begin{tabular}{cccc}
\hline \multirow{2}{*}{ Month } & \multicolumn{3}{c}{ Drought Level Classification } \\
\cline { 2 - 4 } & Medium Dry & Very Dry & Extremely Dry \\
\hline January & 0,00 & 0,00 & 0,00 \\
\hline February & 13,02 & 5,65 & 0,13 \\
\hline March & 0,00 & 0,00 & 0,00 \\
\hline April & 1,22 & 0,00 & 0,00 \\
\hline May & 78,16 & 5,77 & 1,18 \\
\hline June & 8,32 & 0,00 & 0,00 \\
\hline July & 0,00 & 0,00 & 0,00 \\
\hline August & 0,00 & 0,00 & 0,00 \\
\hline September & 2,24 & 0,00 & 0,00 \\
\hline October & 1,49 & 0,00 & 0,00 \\
\hline November & 42,60 & 2,59 & 0,00 \\
\hline December & 27,24 & 8,63 & 0,42
\end{tabular}

Source: Data Processing 2020

In November, the incidence of drought is not as severe as in May. The drought-affected area is almost half of the Trenggalek Regency area, with $42.60 \%$ at the "medium dry" level and $2.59 \%$ at the "very dry" level. This month, most of the incidents hit the central part of the Trenggalek Regency, which stretches from west to east. In December, three rain stations located on the southern coast of Trenggalek Regency experienced drought at a "very dry" level to "extremely dry." The SPI value at the "extremely dry" level that occurred at Watulimo station was the second lowest in 2019. Even though there were only three stations, the impact of the drought was more than a third of the area in the Trenggalek Regency, especially in the southern region.

\section{Analysis of the Effect of Drought and Rice and Secondary Crops Production}

The rise and fall of agricultural productivity cannot be separated from the influence of weather and climate. Often drought disasters that occur due to weather anomalies and climate change make agricultural production decline. It also occurs in rice and secondary crops, which are superior varieties grown by farmers in Trenggalek Regency. The graph of agricultural production in 2019 in the Trenggalek Regency is shown in Figure 3. From the graph, the production of rice and secondary crops is very volatile every month. 
INTENSIF, Vol.5 No.2 August 2021

ISSN: 2580-409X (Print) / 2549-6824 (Online)

DOI: https://doi.org/10.29407/intensif.v5i2.15645

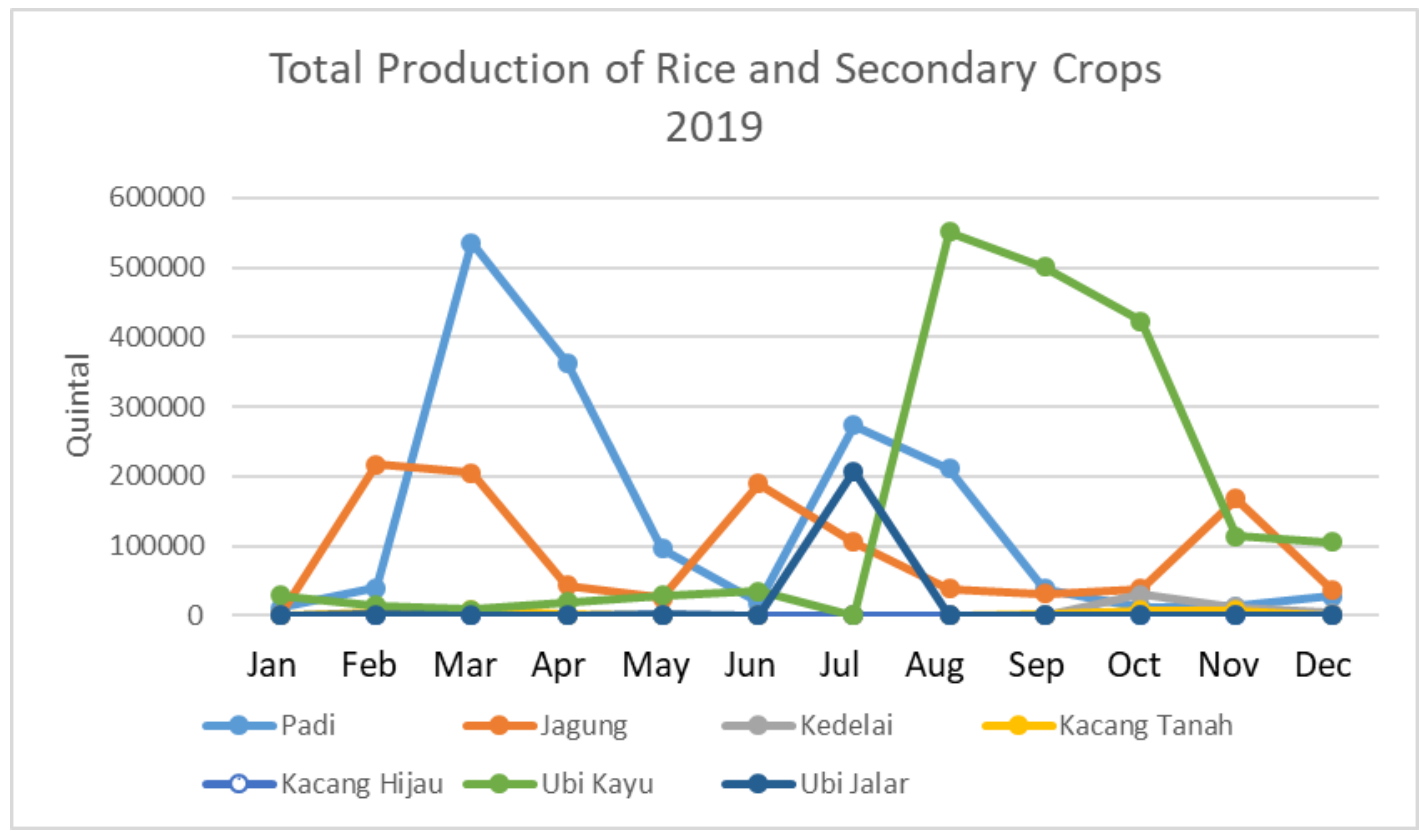

Figure 3. Total Rice And SECONDARY CROPS PRODUCTION In 2019 In TRENGGALEK REGENCY [6]

When SPI 1 at all stations did not have a negative value indicating any drought in March, rice production reached its peak with 535,335 quintals, followed by maize production with 205,188 quintals. The drought that occurred in May in almost all areas of Trenggalek Regency made rice and secondary crops production decrease with a total production of 151,184 quintals, which means that it decreased to $80.06 \%$ of the total production in March. $64.51 \%$ of the technical irrigated area planted with rice twice a year [6] made rice production in July increase again at 273,019 quintals. Despite the increase, the drought that occurred in May still impacted the decline in the number of harvests in the next three months. It was recorded that from June to August, there was a puso (crop failure) on land planted with rice with a total area of 76 hectares, the majority of which occurred in June, covering an area of 52 hectares. [6]. The increase in cassava production, which peaked in August with 550,851 quintals, indicates that farmers tend to switch to planting secondary crops when the drought arrives. When drought occurred again in November in most of the central region and December in the southern part of Trenggalek Regency, the majority of all agricultural production was low. However, corn production increased in November by a total of 168,049 quintals. 
INTENSIF, Vol.5 No.2 August 2021

ISSN: 2580-409X (Print) / 2549-6824 (Online)

DOI: https://doi.org/10.29407/intensif.v5i2.15645

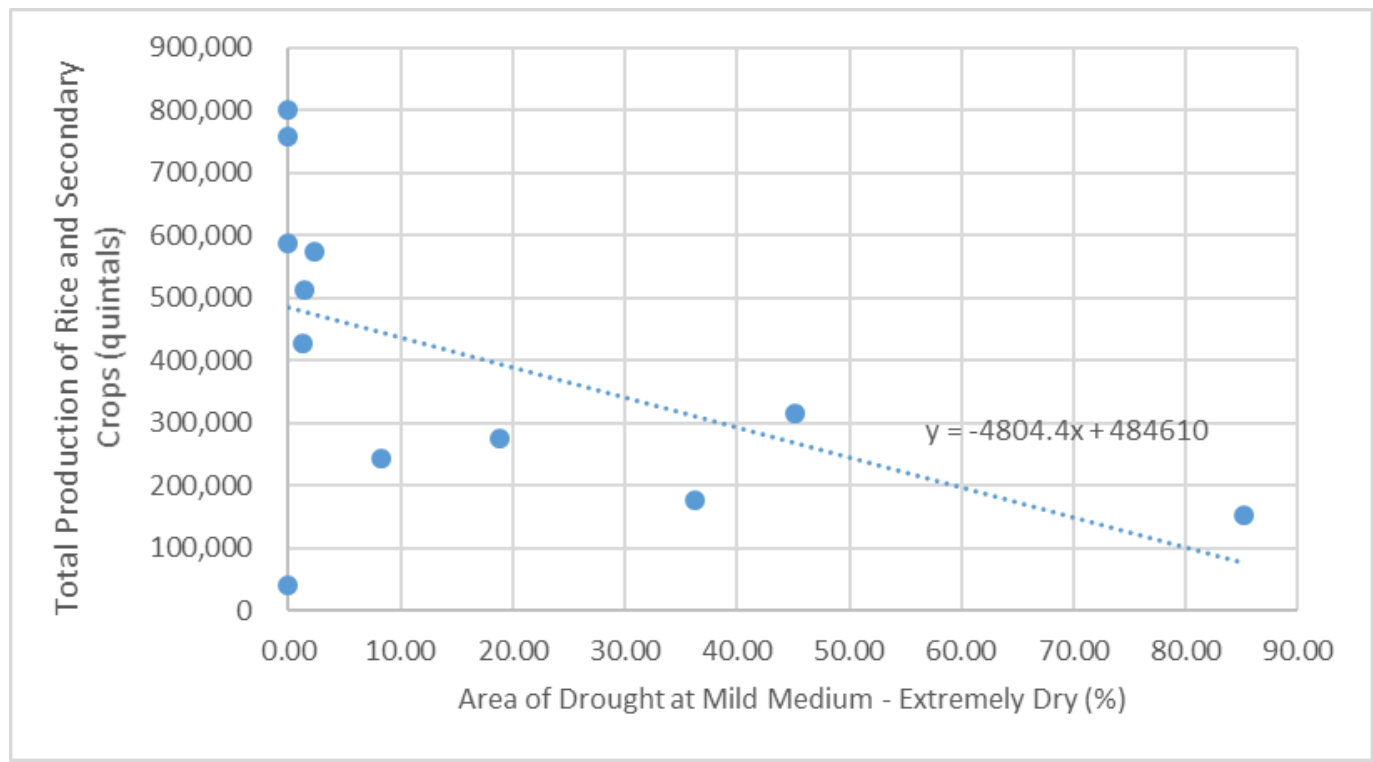

Figure 4. GRAPH OF THE EFFECT OF DROUGHT ON THE AMOUNT OF RICE AND SECONDARY CROPS PRODUCTION IN TRENGGALEK DISTRICT IN 2019

Overall, the effect of drought on the total production of rice and secondary crops is shown in Figure 4. Based on the regression findings, it can be concluded that the two variables have a negative association. It shows that the increase in the area affected by drought affects rice and secondary crop production.

\section{CONCLUSION}

The worst drought in the Trenggalek Regency in 2019 occurred in May covered 85.11\% $(1,062,934 \mathrm{~km} 2)$ of the area from medium to extremely dry levels. The drought caused a decrease in the total production of rice and secondary crops by $80.06 \%$ (606,828 quintals) of the total production during the wet month in March. Rice and corn are varieties that are susceptible to being affected by drought. Cassava can be an alternative that can be planted during the dry season.

\section{ACKNOWLEDGMENTS}

The author would like to thank all those who have assisted in the research process, from data collection to data analysis, so that this paper can be completed properly. The authors would like to thank the National Development Planning Agency through the Pusbindiklatren, which has provided the opportunity and financial support to the author to complete his master's degree studies at Gadjah Mada University in the Environmental Science Study Program with interest in Geo-Information for Disaster Management. 


\section{REFERENCES}

[1] Perdinan, R. F. Adi, and E. Y. Arini, "Regional Analysis of Prone Drought Areas under Future Climate Change Scenarios: Case Study Agropolitan of Malang District," in IOP Conference Series: Earth and Environmental Science, 2017, vol. 58, no. 012024, pp. 18.

[2] M. Hayes, M. Svoboda, N. Wall, and M. Widhalm, "The lincoln declaration on drought indices: Universal meteorological drought index recommended," Bull. Am. Meteorol. Soc., vol. 92, no. 4, pp. 485-488, 2011.

[3] D. A. Wilhite, "Chapter1 Drought as a Natural Hazard," Drought A Glob. Assess., vol. Vol. I, pp. 3-18, Routledge, 2000.

[4] Pemerintah Kabupaten Trenggalek, "Geografi Kabupaten Trenggalek," www.trenggalekkab.go.id, $2019 . \quad$ [Online]. Available: https://www.trenggalekkab.go.id/menu?page=25\&cat=18. [Accessed: 05-Jan-2021].

[5] Badan Penanggulangan Bencana Daerah Kabupaten Trenggalek, "Data Kekeringan Kabupaten Trenggalek," 2020.

[6] Dinas Pertanian dan Pangan Kabupaten Trenggalek, "Data Produksi Pertanian Kabupaten Trenggalek," 2020.

[7] B. Irawan, Dampak El Nino dan La Nina terhadap produksi padi dan palawija. Jakarta: Badan Penelitian dan Pengembangan Pertanian, Kementerian Pertanian, 2013.

[8] E. Surmaini and H. Syahbuddin, "Kriteria Awal Musim Tanam: Tinjauan Prediksi Waktu Tanam Padi Di Indonesia," J. Penelit. dan Pengemb. Pertan., vol. 35, no. 2, p. 47, 2016.

[9] T. B. McKee, N. J. Doesken, and J. Kleist, "The relationship of drought frequency and duration of time scales," in Eight Conference on Applied Climatology, 1993, pp. 179184.

[10] P. Angelidis, F. Maris, N. Kotsovinos, and V. Hrissanthou, "Computation of Drought Index SPI with Alternative Distribution Functions," Water Resour. Manag., vol. 26, no. 9, pp. 2453-2473, 2012.

[11] T. Caloiero, B. Sirangelo, R. Coscarelli, and E. Ferrari, "Occurrence probabilities of wet and dry periods in Southern Italy through the SPI evaluated on synthetic monthly precipitation series," Water (Switzerland), vol. 10, no. 3, 2018.

[12] M. Türkeş and H. Tatli, "Use of the standardized precipitation index (SPI) and a modified SPI for shaping the drought probabilities over Turkey," Int. J. Climatol., vol. 29, no. February 2009, pp. 2270-2282, 2009.

[13] L. Vasiliades and A. Loukas, "A Water Balance Derived Drought Index for Pinios River Basin , Greece," Water Resour. Manag., vol. 25, pp. 1087-1101, 2011.

[14] T. Caloiero and S. Veltri, "Drought Assessment in the Sardinia Region ( Italy ) During 1922 - 2011 Using the Standardized Precipitation Index," Pure Appl. Geophys., vol. 176, no. 2, pp. 925-935, 2019.

[15] R. Kumar et al., "Multiscale evaluation of the Standardized Precipitation Index as a groundwater drought indicator," Hydrol. Earth Syst. Sci., vol. 20, no. 3, pp. 1117-1131, 2016.

[16] J. N. Okpara, E. A. Afiesimama, A. C. Anuforom, A. Owino, and K. O. Ogunjobi, "The applicability of Standardized Precipitation Index: drought characterization for early warning system and weather index insurance in West Africa," Nat. Hazards, vol. 89, no. 2, pp. 555-583, 2017.

[17] S. Zhim, A. Larabi, and H. Brirhet, "Analysis of precipitation time series and regional drought assessment based on the standardized precipitation index in the Oum Er-Rbia basin (Morocco)," Arab. J. Geosci., vol. 12, no. 16, Aug. 2019.

[18] B. S. Sobral et al., "Drought characterization for the state of Rio de Janeiro based on the annual SPI index: trends, statistical tests and its relation with ENSO," Atmos. Res., vol. 
INTENSIF, Vol.5 No.2 August 2021

ISSN: 2580-409X (Print) / 2549-6824 (Online)

DOI: https://doi.org/10.29407/intensif.v5i2.15645

220, no. December 2018, pp. 141-154, 2019.

[19] M. M. Rashid and S. Beecham, "Development of a non-stationary Standardized Precipitation Index and its application to a South Australian climate," Sci. Total Environ., vol. 657, pp. 882-892, Mar. 2019.

[20] E. Surmaini, E. Susanti, M. R. Syahputra, and T. W. Hadi, "Exploring Standardized Precipitation Index for predicting drought on rice paddies in Indonesia," IOP Conf. Ser. Earth Environ. Sci., vol. 303, no. 1, 2019.

[21] L. Wang, G. Huang, and W. Chen, "Towards a theoretical understanding of multiscalar drought indices based on the relationship between precipitation and standardized precipitation index," Theor. Appl. Climatol., vol. 136, no. 3-4, pp. 1465-1473, May 2019.

[22] H. Saidah, M. Bagus Budianto, and L. Hanifah, "Analisa Indeks dan Sebaran Kekeringan Menggunakan Metode Standardized Precipitation Index (SPI) dan Geographical Information System (GIS) untuk Pulau Lombok," J. Spektran, vol. 5, no. 2, pp. 173-179, Jul. 2017.

[23] R. Widyastuti, M. P. Tambunan, R. P. Tambunan, and K. Simpenan, "Pola Sebaran Kekeringan di Kecamatan Simpenan Menggunakan Metode SPI (Standardized Precipitation Index)," J. Geosaintek, vol. 6, no. 1, pp. 19-24, 2020.

[24] M. A. Khan and M. S. Gadiwala, "A Study of Drought over Sindh ( Pakistan ) Using Standardized Precipitation Index ( SPI ) 1951 to 2010," Pakistan J. Meteorol., vol. 9, no. 18, pp. 15-22, 2013.

[25] A. Annugerah, I. F. Astuti, and A. H. Kridalaksana, "Sistem Informasi Geografis Berbasis Web Pemetaan Lokasi Toko Oleh-Oleh Khas Samarinda," J. Inform. Mulawarman, vol. 11, no. 2, 2016.

[26] H. Satyawardhana and A. Susandi, "Proyeksi Awal Musim di Jawa Berbasis Hasil Downscaling Conformal Cubic Atmospheric Model (CCAM)," J. Sains Dirgant., vol. 13, no. 1, pp. 1-14, 2015.

[27] T. Maharani, "Pemodelan Bahaya Kekeringan Meteorologis Di Provinsi Jawa Timur Dengan Menggunakan Data CHIRPS (Climate Hazards Group Infrared Precipitation With Station Data)," Tesis, Universitas Gadjah Mada, 2019.

[28] B. Lloyd-Hughes and M. A. Saunders, "A drought climatology for Europe," Int. J. Climatol., vol. 22, no. 13, pp. 1571-1592, 2002. 